\title{
Development of an innovative one part green concrete
}

\author{
Ourania Tsioulou, Andreas Lampropoulos \\ University of Brighton, UK \\ Kyriacos Neocleous, Nicholas Kyriakides, Thomaida Polydorou \\ Cyprus University of Technology, Cyprus
}

Contact: $\underline{\text { o.tsioulou@brighton.ac.uk }}$

\begin{abstract}
Concrete is one of the most commonly used construction materials. However, the main drawbacks in the use of concrete are related to the use of cement and subsequently the high percentage of carbon dioxide emissions. The use of cement substitutes is an area where there is a lot of ongoing research. Geopolymer concrete is a concrete in which cement is replaced by waste materials such as Pulverised Fuel Ash (PFA), or Ground Granulated Blast Slag (GGBS). To activate the geopolymerisisation, an alkali activator is used. The procedure, which is used for the production of a geopolymer concrete, is normally a two-part procedure: Preparation of the alkali activator one day before the mixing and mixing of the aluminosilicate sources (PFA, GGBS) with the activator. To make the production of geopolymers more user friendly it needs to be converted to one part procedure where water will be added in a readymade mix. In the published literature, there is research on one part geopolymers, but there are limited studies on the use of demolition waste materials as substitution of PFA and GGBS in this type of materials. With the current study, different sources of raw materials focusing on demolition waste materials such as red bricks and reclaimed concrete, which are commonly used in constructions worldwide, will be examined for the production of one part geopolymer. The major aim of this research proposal is to develop an innovative sustainable one part cement free geopolymer concrete. The new concrete is a "green" concrete where cement is replaced by waste materials. Construction demolition materials such as red bricks can be used as raw materials in the geopolymer matrix. This project will focus on the selection, characterisation and development of the appropriate processing of these red bricks so as they can be used as raw materials in the geopolymer matrix. Also, the development of one part mix so as the new concrete to be ready for use by adding only water in it, is another aim of the proposed project.
\end{abstract}

Keywords: cement-free concrete; one-part geopolymer. 


\section{Introduction}

Worldwide there is an ever-increasing pressure for countries, governments and companies to become greener and reduce carbon emissions in an attempt to help prevent climate change. This can be seen in renewable energy targets given to countries across Europe. For example, in the Renewables Directive published in 2009, the UK was set the target that by the year $2020,15 \%$ of its energy consumption would come from renewable sources [1].

Concrete is the most widely used construction material. Concrete is responsible for $5 \%$ of annual anthropogenic carbon dioxide $\left(\mathrm{CO}_{2}\right)$ production. The major contributing factor to $\mathrm{CO}_{2}$ emissions in the concrete industry is cement production, with around 1.1 tonnes of $\mathrm{CO}_{2}$ produced per metric tonne of cement [10]. The majority of $\mathrm{CO}_{2}$ is produced when Calcium Carbonates $\left(\mathrm{CaCO}_{3}\right)$ are heated at high temperatures in a kiln producing calcium oxides $(\mathrm{CaO})$ and $\mathrm{CO}_{2}$. This $\mathrm{CO}_{2}$ has no further use and is subsequently released into the atmosphere.

One way for reducing the environmental impacts related to the use of concrete is by reducing the amount of cement, which is used. This has been done with the development of geopolymer concrete in which cement has been replaced (partially or as a whole) by waste materials such as Pulverised Fuel Ash (PFA) and Ground Granulated Blast Slag (GGBS).

In geopolymers, to activate the geopolymerisation, alkali activators (usually a combination of $\mathrm{Na}$ silicate solution and $\mathrm{NaOH}$ ) are used. These chemicals should be mixed together $24 \mathrm{hrs}$ prior to the final concrete mix and as a result, the mixing procedure is a two part procedure. To make the production of geopolymers more user friendly it needs to be converted to one part procedure where water will be added in a readymade mix. In literature, there are examples of research on the one part geopolymers but in most of them, the basic waste material that is used as cement substitution is PFA [2-8]. The last few years PFA stock in the UK is very limited and new sources of waste materials, which can substitute PFA need to be found [9]. With the current study, demolition waste materials such as red bricks which are commonly used in constructions in the UK and in Cyprus, will be examined as raw material for the production of an one part geopolymer with improved mechanical properties.

\section{Geopolymer material preparation}

\subsection{Materials and mix design}

Fly ash (FA) category S according to BS EN-450 [10] and powder from recycled red bricks, were used in the current study as geopolymer binders (Figure 1). Silica sand with a maximum particle size of $500 \mu \mathrm{m}$ and normal river sand were used as aggregates (Figure 1). For the alkaline activator, $\mathrm{NaOH}$ in powder form was used.

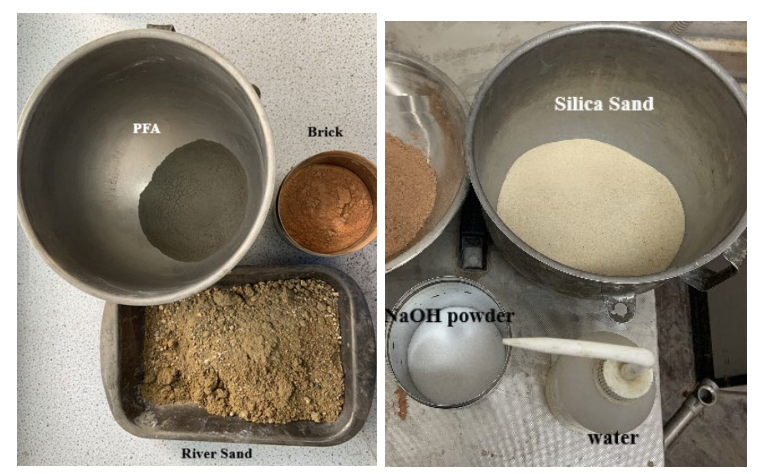

Fig. 1 Materials

Chemical compositions for the PFA and the silica sand as received from the supplier are shown in Table 1. Recycled red bricks which were used in the mix design, were also examined and their chemical composition is given in Table 1 as well.

Table 1. Chemical composition of PFA and Silica sand (as received from the manufacturer) and for red bricks

\begin{tabular}{cccc}
\hline $\begin{array}{c}\text { Chemical } \\
\text { Compositions } \\
\text { [\%] }\end{array}$ & Fly Ash & $\begin{array}{c}\text { Red } \\
\text { Bricks }\end{array}$ & $\begin{array}{c}\text { Silica } \\
\text { Sand }\end{array}$ \\
\hline $\begin{array}{c}\text { Silicon } \\
\text { dioxide, } \mathrm{SiO}_{2}\end{array}$ & 59 & $40-50$ & 99.73 \\
\hline $\begin{array}{c}\text { Aluminum } \\
\text { Oxide, } \mathrm{Al}_{2} \mathrm{O}_{3}\end{array}$ & 23 & $5-10$ & 0.1 \\
\hline $\begin{array}{c}\mathrm{Calcium} \\
\text { Oxide, } \mathrm{CaO}\end{array}$ & 2.38 & -- & -- \\
\hline $\begin{array}{c}\text { Ferric } \mathrm{Oxide}_{2} \\
\mathrm{Fe}_{2} \mathrm{O}_{3}\end{array}$ & 8.8 & $5-10$ & 0.051 \\
\hline $\begin{array}{c}\text { Sulfate } \\
\text { trioxide, } \mathrm{SO} 3\end{array}$ & 0.27 & -- & -- \\
\hline
\end{tabular}




\begin{tabular}{cccc}
\hline $\begin{array}{c}\text { Sodium } \\
\text { Oxide, } \mathrm{Na}_{2} \mathrm{O}\end{array}$ & 0.74 & -- & $<0.05$ \\
\hline $\begin{array}{c}\text { Potassium } \\
\text { Oxide, } \mathrm{K}_{2} \mathrm{O}\end{array}$ & 2.81 & -- & 0.01 \\
\hline $\begin{array}{c}\text { Albite, } \\
\mathrm{NaAlSi}_{3} \mathrm{O}_{3}\end{array}$ & -- & 40 & -- \\
\hline $\begin{array}{c}\text { Magnesium } \\
\text { Oxide, } \mathrm{MgO}\end{array}$ & 1.39 & -- & -- \\
\hline \hline
\end{tabular}

As has been mentioned above, red bricks from construction and demolition waste in Cyprus was ground and used in the mixes in the form of powder.

Grading curve for the brick powder, which was used in the mixes, is presented in Figure 2.

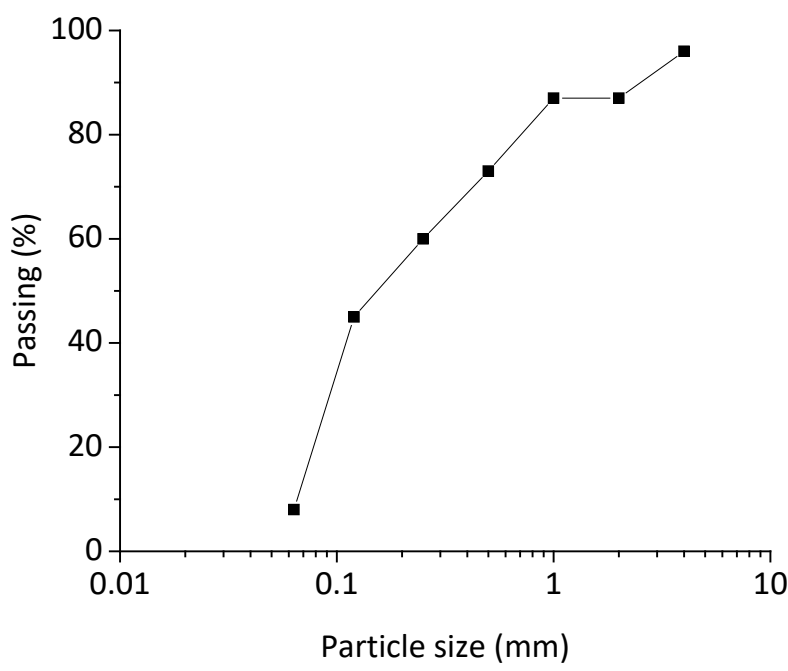

Fig. 2 Grading of brick powder used in the mixes

Eleven in total different geopolymer mix designs were tested (Table 2, 3 and 4).

Initially a mix designed, based on the mix designs which are presented in [5], was developed using as binder a combination of PFA and Brick's powder, and as aggregates silica sand. The water/ binder ratio equals to 0.23 was used as it is suggested in the literature [5] but the mixes were too dry that they weren't workable at all. As a result, the mixes were repeated with increased water/binder ratio, equal to 0.35 (Table 2).

Table 2. Geopolymermix composition with silica sand and water/binder $=0.35$

\begin{tabular}{cccc}
\hline & \multicolumn{3}{c}{ Mix Designs } \\
\hline $\begin{array}{c}\text { Material } \\
\left(\mathrm{kg} / \mathrm{m}^{3}\right)\end{array}$ & M1 & M2 & M3 \\
\hline Fly ash & 469 & 234.5 & - \\
\hline
\end{tabular}

\begin{tabular}{cccc}
\hline Red brick & - & 234.5 & 469 \\
\hline $\mathrm{NaOH}$ & 75 & 75 & 75 \\
\hline Water & 164 & 164 & 164 \\
\hline Silica Sand & 1559 & 1559 & 1559 \\
\hline
\end{tabular}

The same mixes using both water/binder ratios ( 0.23 and 0.35 ) were also examined with different combinations of PFA and brick's powder but using river sand as aggregates (Table 3 and 4).

Table 3. Geopolymer mix composition with river sand and water/binder $=0.23$

\begin{tabular}{ccccc}
\hline \multicolumn{5}{c}{ Mix Designs } \\
\hline $\begin{array}{c}\text { Material } \\
\left(\mathbf{k g} / \mathbf{m}^{3}\right)\end{array}$ & M4 & M5 & M6 & M7 \\
\hline Fly ash & 469 & 375.2 & 234.5 & \\
\hline Red brick & - & 93.8 & 234.5 & 469 \\
\hline NaOH & 75 & 75 & 75 & 75 \\
\hline Water & 112 & 112 & 112 & 112 \\
\hline $\begin{array}{c}\text { Normal } \\
\text { Sand }\end{array}$ & 1559 & 1559 & 1559 & 1559 \\
\hline
\end{tabular}

Table 4. Geopolymer mix composition with river sand and water/binder $=0.35$

\begin{tabular}{ccccc}
\hline \multicolumn{5}{c}{ Mix Designs } \\
\hline $\begin{array}{c}\text { Material } \\
\left(\mathbf{k g} / \mathbf{m}^{3}\right)\end{array}$ & M8 & M9 & M10 & M11 \\
\hline Fly ash & 469 & 375.2 & 234.5 & 93.8 \\
\hline Red brick & - & 93.8 & 234.5 & 375.2 \\
\hline $\mathrm{NaOH}$ & 75 & 75 & 75 & 75 \\
\hline Water & 164 & 164 & 164 & 164 \\
\hline $\begin{array}{c}\text { Normal } \\
\text { Sand }\end{array}$ & 1559 & 1559 & 1559 & 1559 \\
\hline
\end{tabular}

\subsection{Mixing procedure}

To prepare the geopolymer mortars, specimens were mixed using a $5 \mathrm{~L}$ Hobart mixer (Fig. 3).

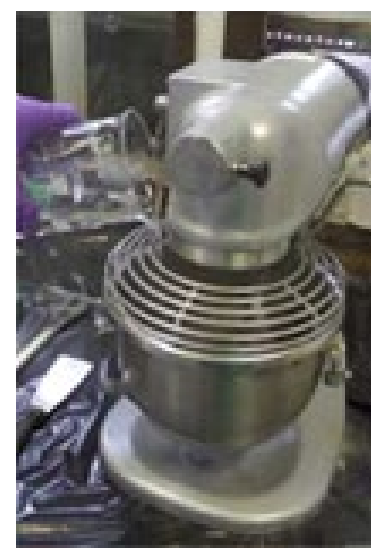


Fig. 3 Mixing Geopolymer mortar

Two different mixing procedures were followed. According to the first procedure (mixing procedure A) binder and aggregates were mixed together for 5 minutes and then $\mathrm{NaOH}$ solution was added and mixed all together for 5 more minutes.

According to the second procedure (mixing procedure $\mathrm{B}$ ), all solids, binder, aggregates and $\mathrm{NaOH}$ were mixed together for 5 minutes and then water was added and mixed all together for 5 more minutes.

Mixes M4, M6 and M7 were repeated using both mixing procedures, while the rest of the mixes were tested only using the mixing procedure $B$.

All the samples after casting were cured in oven at $85^{\circ} \mathrm{C}$ for 24 hours.

Results for the compressive strength of all the mixes are presented in the following section.

\section{Results}

Compressive strength and microstructure of the mix designs are presented in this section

\subsection{Compressive strength}

For each of the mixes, in total three $50 \mathrm{~mm}$ cubes were cast and tested under compression. Some of the samples are given in Figure 4 below.

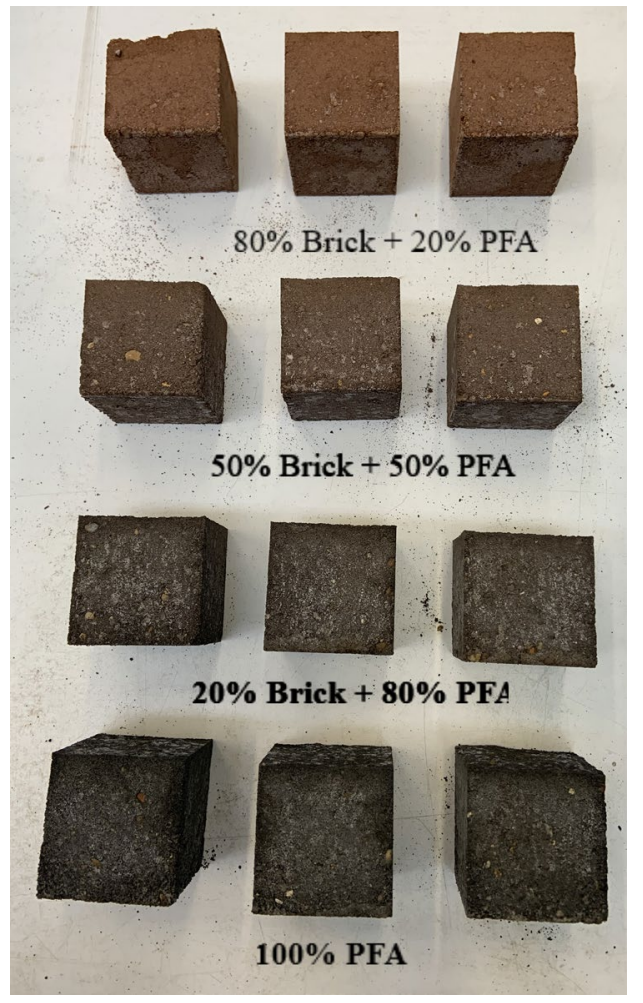

Fig. 4 Cubic samples of the mixes

Compressive strength of all the mixes are given in Table 5. The values are presented in the Table 5 are the average values of all 3 specimens which were tested for each of the mixes.

Table 5. Compressive strength for the different mixes

\begin{tabular}{lll}
\hline & \multicolumn{2}{c}{$\begin{array}{c}\text { Mean Compressive Strength } \\
\text { (MPa) }\end{array}$} \\
\hline & $\begin{array}{l}\text { Mixing } \\
\text { procedure B }\end{array}$ & $\begin{array}{l}\text { Mixing } \\
\text { procedure A }\end{array}$ \\
\hline M1 (M8) & 4.95 & \\
\hline M2 (M10) & 4.07 & \\
\hline M3 & 0 & 50 \\
\hline M4 & 3.66 & \\
\hline M5 & 2.9 & 46 \\
\hline M7 & 1.82 & 40 \\
\hline M8 & 1.28 & \\
\hline M9 & 23.2 & \\
\hline M10 & 22.62 & \\
\hline M11 & 12.72 \\
\hline
\end{tabular}

In Figures 5 and 6 below the effect of the type of sand and the water/binder ratio on the compressive strength of the mixes for different combinations of PFA and brick's powder, is presented. 


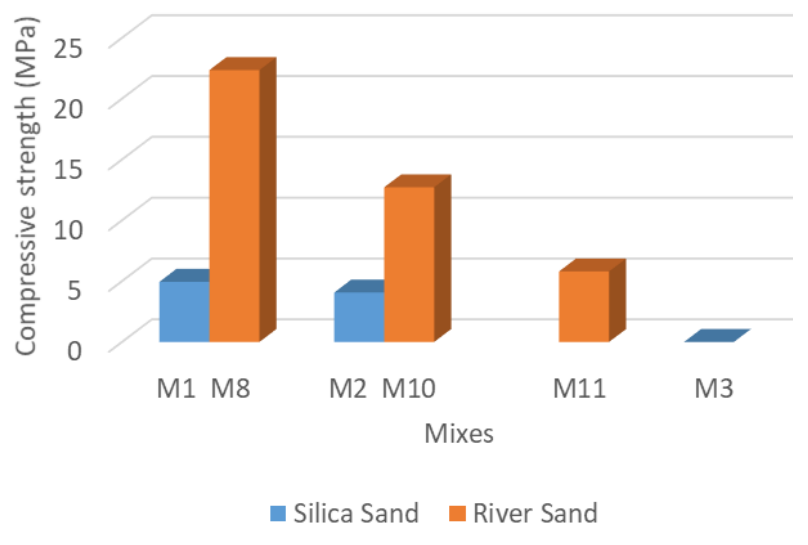

Fig. 5 Effect of the type of sand on the compressive strength

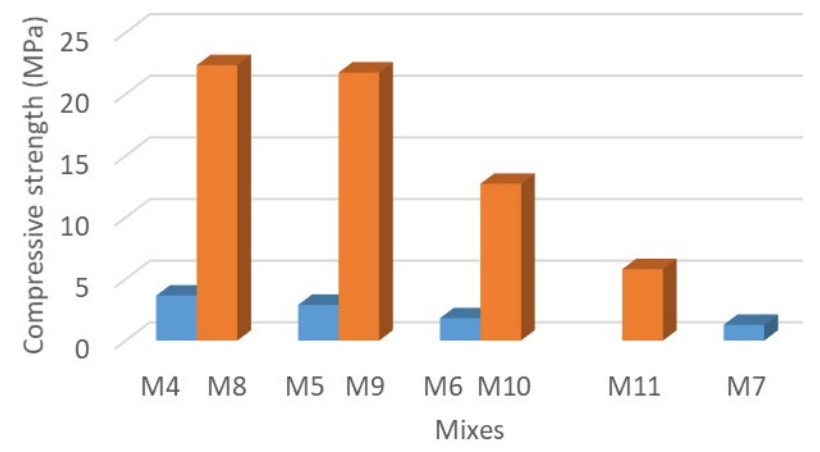

water $/$ binder $=0.23$ water $/$ binder $=0.35$

Fig. 6 Effect of the water/binder ratio on the compressive strength

It can be seen that replacement of silica sand with normal river sand has led to an increase of the compressive strength, while the replacement of PFA with the brick powder has led to a reduction of the mix's compressive strength. Nevertheless, it can be observed that $20 \%$ substitution of PFA with brick powder, using the river sand has given a compressive strength of $23.2 \mathrm{MPa}$; this mix can be used in floor tiles. Increasing the \% of brick powder which substitutes the PFA, the compressive strength reduces with the mix with $50 \%$ brick powder giving a compressive strength of 12.72 MPa. A mix like this can be used as a mortar in many applications like masonry foundations and brick patios.

\subsection{Microstructure of the mixes}

The microstructure of the different mix designs have been examined using the Scanning Electron Microscope (SEM) analysis. In Figures 7 and 8, a comparison between the microstructure of $\mathrm{M} 8$ and M10 mixes is presented to identify the effect of the brick powder on the mix characteristics.
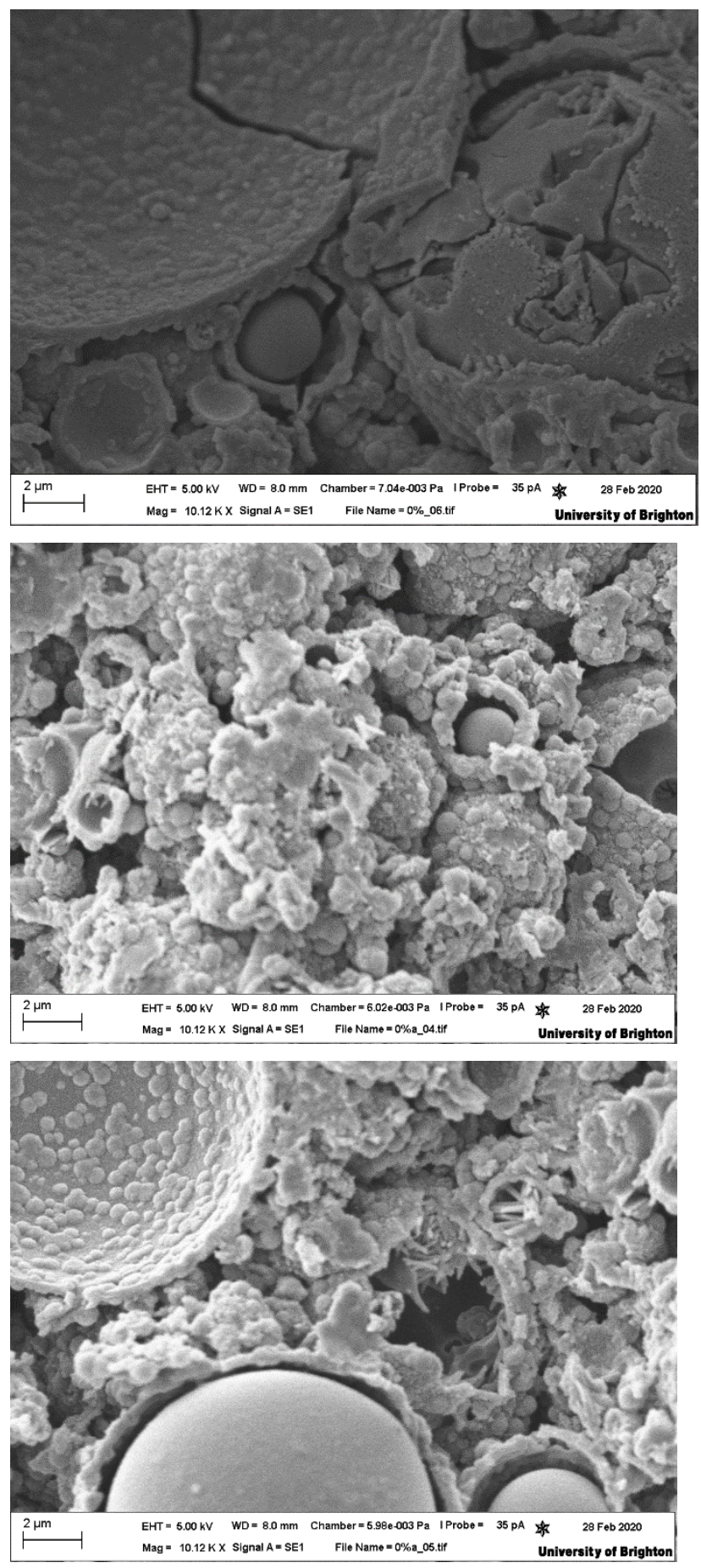

Fig. 7 Microstructure of M8 using SEM analyses 

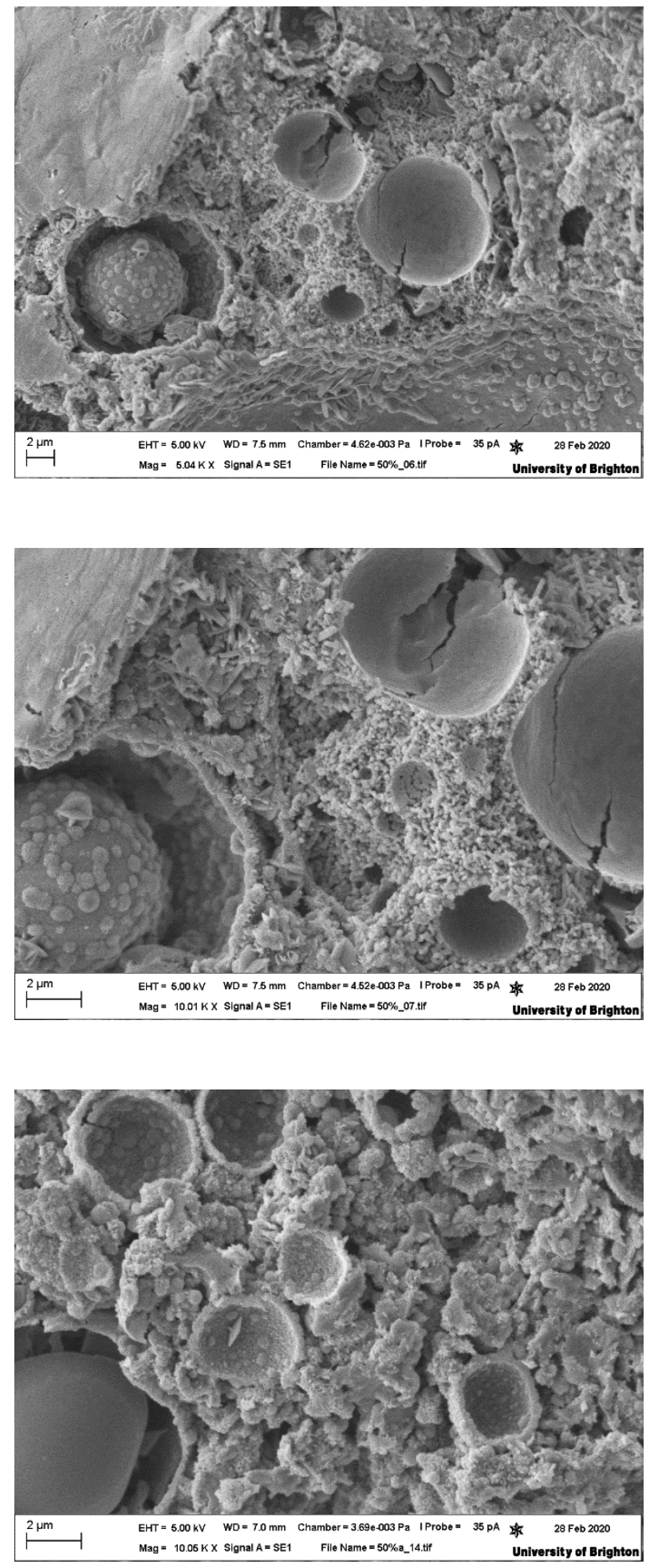

Fig. 8 Microstructure of M10 using SEM analyses

By substituting PFA with brick's powder, the calcium content of the mix is reduced. This has as a result inclusion of bricks powder which leads to less calcium bearing compounds, less binding product and as a result more porosity and less compressive strength.

\section{Conclusions}

In the current paper an experimental investigation on the development of an one-part geopolymer mortar using powder from recycled red bricks from constructions demolition, as replacement of PFA, has been accomplished.

It has been found that replacement of PFA with red bricks powder has led to the reduction of the compressive strength of the mixes. This can also be seen from the SEM analyses where mixes with brick powder has given higher porosity.

In terms of compressive strength, Mix M9 gave 22.62MPa and $\mathrm{M} 8$ gave 23.2MPa. A material with this range of compressive strength, an application of this material can be in floor tiles.

\section{References}

[1] European Parliament \& Council. Directive 2009/28/EC of the European Parliament and of the Council of 23 April 2009 on the promotion of the use of energy from renewable sources and amending and subsequently repealing. Official Journal of the European Union; 2009.

[2] Nematollahi B., Sanjayan J., Qiu J. and Yang E. Micromechanics-based investigation of a sustainable ambient temperature cured one-part strain hardening geopolymer composite. Construction and Building Materials. 2017; 131: 552-563

[3] Peys A., Arnout L., Blanpain B., Rahier H., van Acker K. and Pontikes Y. Mix-design Parameters and Real-life Considerations in the Pursuit of Lower Environmental Impact Inorganic Polymers. Waste Biomass Valorisation. 2017; 9: 879-889.

[4] Abdollahnejad Z., Miraldo S., Pacheco-Torgal F. and Aguiar J.B. Cost-efficient one-part alkali-activated mortars with low global warming potential for floor heating systems applications. European Journal of Environmental and Civil Engineering. 2017; 21: 412-429.

[5] Yang K., Song J. and Song K. Assessment of $\mathrm{CO}_{2}$ reduction of alkali-activated concrete. 
Journal of Cleaner Production. 2013; 39: 265272.

[6] Yang K., Lee K., Song J. and Gong M. Properties and sustainability of alkaliactivated slag foamed concrete. Journal of Cleaner Production. 2014; 68: 226-233.

[7] Habert G. and Ouellet-Plamondon C. Recent update on the environmental impact of geopolymers. RILEM Technical Letters, 2016; 1: 17-23.

[8] Ouellet-Plamondon C. and Habert G. Life cycle assessment (LCA) of alkali-activated cements and concretes. F. Pacheco-Torgal, J. Labrincha, C. Leonelli, A. Palomo, P. Chindaprasit (Eds.), Handbook of AlkaliActivated Cements, Mortars and Concretes, Elsevier, Amsterdam 2014: 663-686.

[9] Whittaker M.J., Grigoriades K., Soutsos M., Sha W., Klinge A., Paganoni S., Casado M., Brander L., Mousavi M., Scullin M., Correia R., Zerbi T., Staiano G., Merli I., Ingrosso I., Attanasio $A$. and Largo A. Novel construction and demolition waste (CDW) treatment and uses to maximize reuse and recycling. Advances in Building Energy Research, 2019;1-17.

[10] BS EN 450-1. Fly ash for concrete. Definition, specifications and conformity criteria. British Standards Institute; 2012. 